Historic, Archive Document

Do not assume content reflects current scientific knowledge, policies, or practices. 



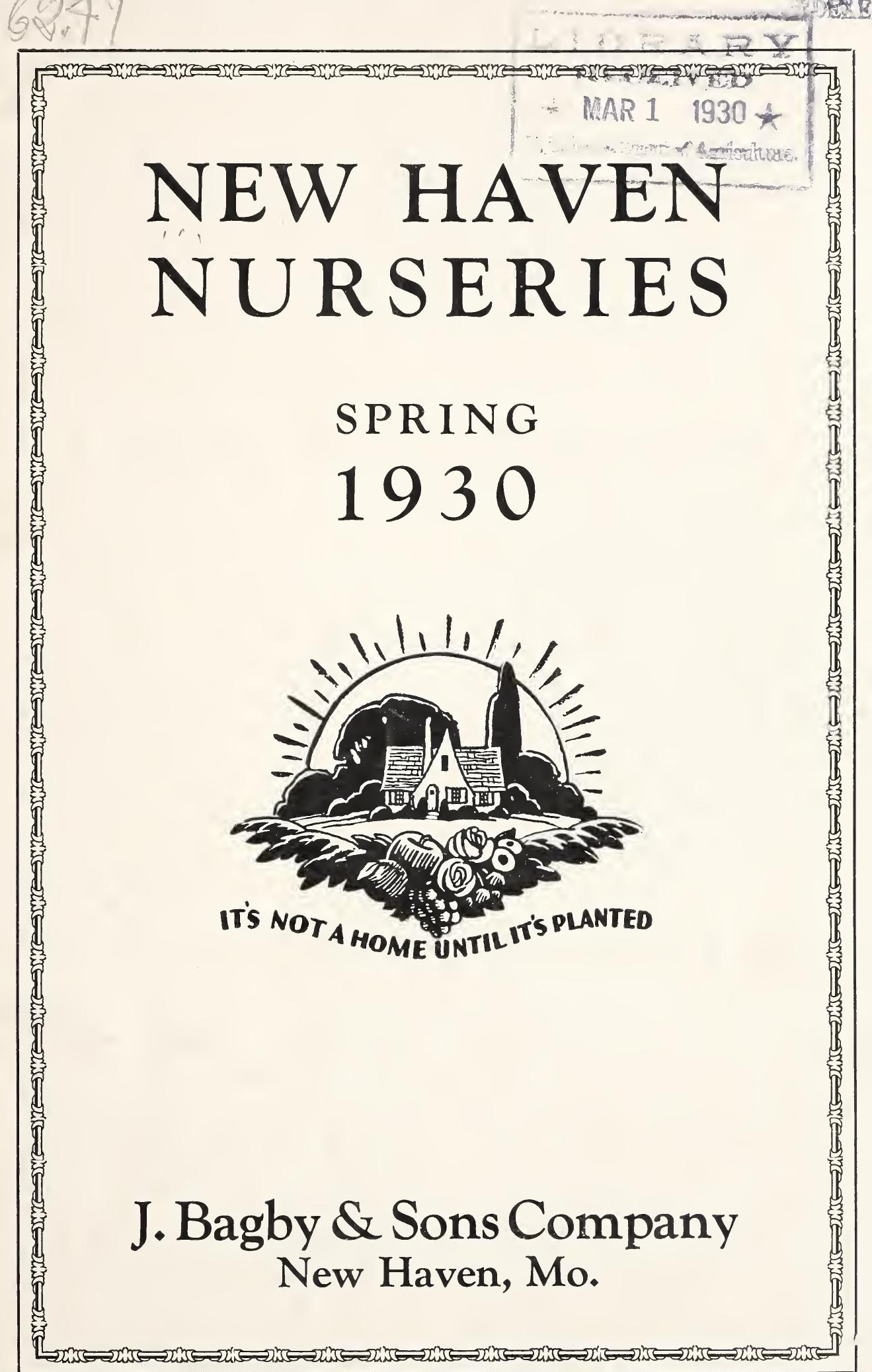




\section{Just About Ourselves}

Fifty-eight years have been spent in building up our nursery business at New Haven. It was established in 1872 by Julian Bagby. Our employees have grown up in the business and are honored citizens of the community. We state this fact that our customers may know that their orders are handled by responsible men. All of the trees we offer are grown on our own land and under our own care. We are proud of our record of the orchards that are growing in every state from the trees we have produced. Scme of our customers have been with us for more than forty years, and we expect to keep right on serving a larger circle of new customers every year with Bagby quality trees. This list contains only the standard, time-tried and tested varieties.

Our years of experience in the nursery business have taught us that our customers like our way of doing business, for they know that we do not exaggerate the merits of our varieties. We produce good stock, true-to-name, pack it well, ship it promptly and in good condition, and charge only reasonable prices. Let us fill your order.

\section{The Way We Do Business With You}

Terms Cash, unless otherwise agreed upon. All orders to be sent C. O. D. must be Registered Letter or Check.

Order Early It is important that you order early. For the benefit of customers who wish to order early, but do not care to spare all of the money when the order is sent, we will accept early orders if 10 per cent of the amount is sent with order, and we will reserve the stock for you. Balance to be sent when you order the stock shipped.

Directions for Ordering Write name and address plainly. Always state disthe grades given in this list. When varieties named cannot be furnished, we reserve the right to substitute such varieties as will fill the season as nearly as possible, unless prohibited in the order. Persons unacquainted with the different varieties will generally get a much better selection by leaving the assortment to us. Keep a correct copy of the order, so that when stock arrives you will know exactly whether you get what you have ordered. If we make mistakes, they are accidental, and we wish to right them.

Prices The prices are for the quantities named, but five, fifty and five hundred will be Prices supplied at ten, hundred and thousand rates respectively-i. e., five at half the price of ten; fifty at half the price of one hundred, and so on.

The prices in this list are for the goods F. O. B. New Haven, Missouri. In our earnest endeavor to be fair with all our customers, we have discontinued the prepayment of freight.

Packing All goods are packed free. Notwithstanding this fact, we use the utmost customers' best interests. Everything is correctly labeled.

Our Guaranty The fact that nurserymen, planters and fruit growers of the country given by any other nursery of fifty-eight years' standing. If a mistake occurs we will cheerfully correct it. We use the greatest care possible to have our stock true-to-name, and should any prove not true, we stand ready to replace it free of charge, or to refund the purchase price, but it is mutually agreed between the purchaser and ourselves that we shall not at any time be held responsible for any sum greater than the amount originally paid for said stock. We guarantee stock to reach customers in good condition.

All shipments will be accompanied by Certificate of Inspection of the State Entomolo. gist. Good stock, true-to-name, sold direct to the planter at reasonable prices is our aim.

We solicit correspondence and personal inspection of our stock, confident that it will compare favorably with the best.

Our Location NEW HAVEN is on the Missouri Pacific Railroad and also on the very best for producing well-ripened stock with splendid roots. Our facilities for prompt shipments are first class. Daily Truck Service to St. Louis.

Our Shipments Our shipments go to practically every State in the Union. We do but we do want to impress on you the fact that there is NONE BETTER. 


\section{APPLES}

The first fruit, both in importance and general culture, is the Apple. Its period, unlike that of all other fruits, extends nearly or quite through the year. By planting judicious selections of summer, fall and winter sorts, a constant succession of this most desirable fruit will be obtained. Apple planting can never be overdone.

Our apples are all grown on Missouri river upland, on well-branched, whole roots, smooth, clean and well grown in every respect. No better trees can be found anywhere.

2 year, 5 to 6 feet, well branched, select.........\$0.45

2 year, 4 to 5 feet, well branched, first-class.......... .40

1 year, 3 to 4 feet, select, or 2 year, 3 to 4 feet ...... . 35

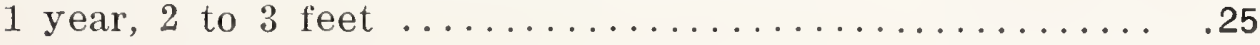

\begin{tabular}{|c|c|c|}
\hline 10 & 100 & 1000 \\
\hline$\$ 4.00$ & $\$ 30.00$ & $\$ 250$. \\
\hline 3.50 & 25.00 & \\
\hline 3.0 & 20.00 & \\
\hline 2.00 & 15.00 & \\
\hline & & \\
\hline$\$ 0$ & 4.00 & \\
\hline & 3.00 & \\
\hline
\end{tabular}

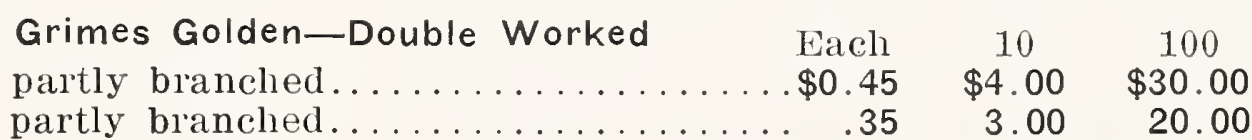

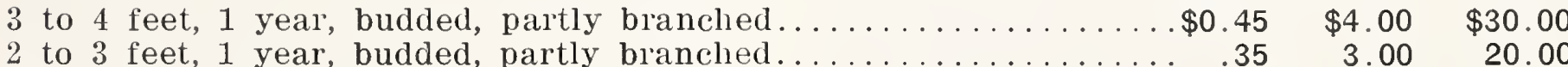

\section{Summer Apples}

BENONI-One of the best summer sor's. Red striped. Flesh yellow, tender, pleasant. Core small. Tree vigorous and upright.

CAROLINA RED JUNE (Red June)-Medium size; red, flesh white; last of June. Tree is very vigorous, upright, an early and abundant bearer.

DUCHESS OF OLDENBURG (Russian)Medium to large size; skin yellow, streaked with red, somewhat blushed. Productive. August.

EARLY HARVEST-Medium to large, bright straw color; flesh white. Tree moderately vigorous and productive. First of July.

LIVELAND RASPBERRY-Fruit good sized, clear, waxen, white striped and marbled crimson; flesh snow-white, often tinged pink next to the skin, a very popular early summer variety. Blooms late, is blight-resistant, bears early, makes a good filler.

RED ASTRACHAN-Fruit large, roundish, juicy. Very hardy.

YELLOW TRANSPARENT-This valuable apple is said to be of Russian origin. We find it to be a valuable addition to our list. Medium to large; nearly white.

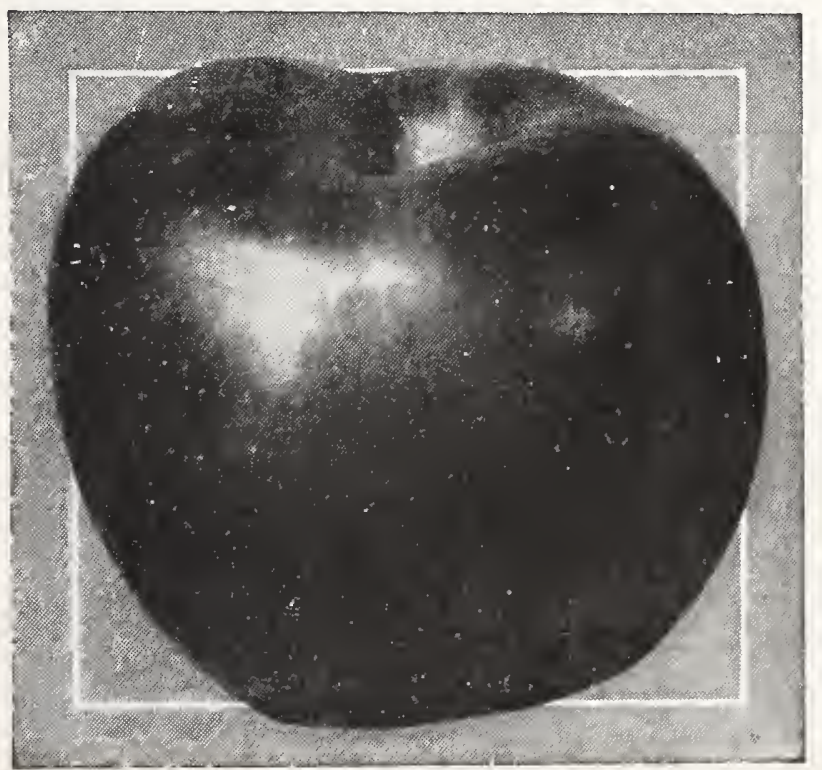

Carolina Red June
Fall Apples

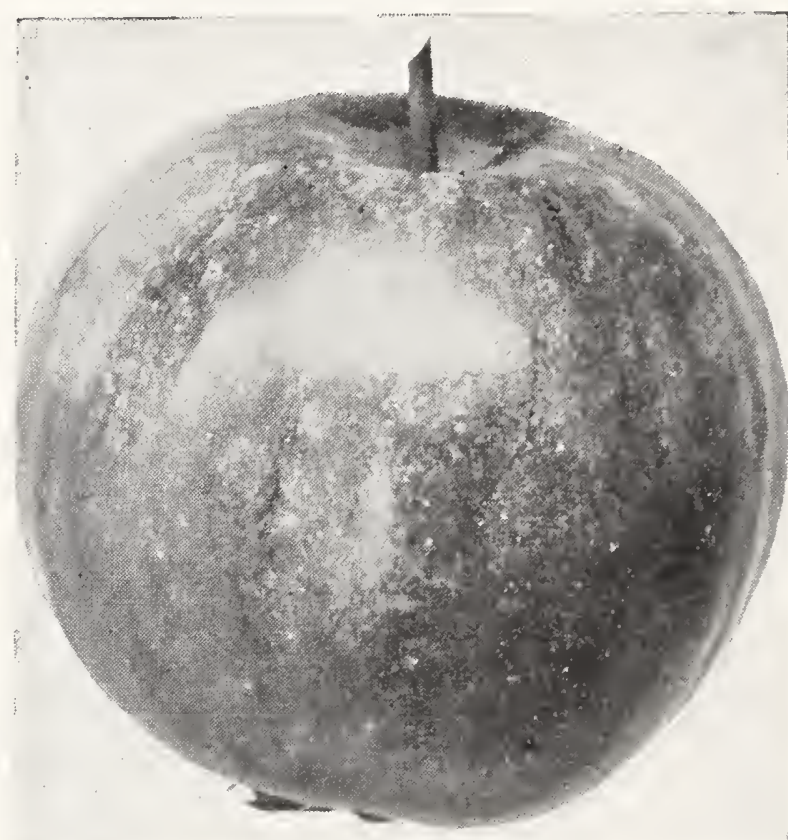

Grimes' Golden

GRIMES' GOLDEN-Medium to large; rich golden-yellow; flesh tender, mild, sub-acid. Should be gathered before turning yellow and put in a cool place. Often keeps until February. Tree hardy, vigorous; an early and abundant bearer. October to January.

GOLDEN SWEET-Large pale yellow. Very sweet.

MAIDEN'S BLUSH-Rathel large, evenly shaded red cheek or blush on a clear pale yellow ground; bears large crops. August and September.

WEALTHY-An apple of fine appearance and quality; an early and profuse bearer; a good market apple of its season. Tree hardy. Ripens here in August. Winter apple North.

WOLF RIVER-Very large; flesh whitish, sub-acid, good bearel. Vely handsome and slowy. November and December. 


\section{Winter Apples-Continued}

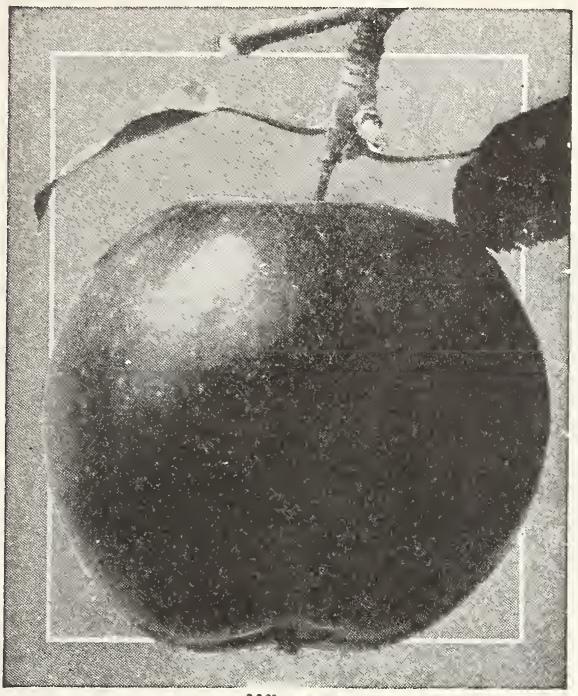

Winesap

WINESAP-Medium, dark red; a favorite market variety. November to April.

WINTER BANANA-Fancy market fruit; large, pale yellow, pink blush. Tree a strong grower.

YORK IMPERIAL-This apple has been gaining favor, and is being planted largely as a commercial sort. Large, smooth, yellow, shaded red, with indistinct red stripes.

\section{Crab Apples}

Prices for Crab Apples are the same as for other apples.

HYSLOP-Deep crimson. Very pcpular on account of its large size, beauty and hardiness. Keeps well into the winter.

TRANSCENDENT - Remarkably vigorous, growing to a good size, and immensely productive. Bears a little the second year from planting, and every year after, and produces good crops by the fourth year. The best of its class for cooking and eating; juicy and crisp. Skin yellow, striped with red. September to October.

WHITNEY-Large, averaging $1 \frac{1 / 2}{2}$ to 2 inches in diameter; skin smooth, glossy green, splashed with carmine; flesh firm, juicy and rich. Very hardy, vigorous, handsome.

YELLOW SIBERIAN-Fruit large, very juicy and excellent for preserves, jelly or pickles.

Pike Co., Mo., Nov. 15, 1929.

I received trees $\mathrm{O} . \mathrm{K}$. in good shape.

J. WARDLOW.

Clark Co., Ill., Nov. 5, 1929.

Received trees and am much pleased with them. FRANK TOBIAS.

St. Louis, Mo., Nov. 18, 1929. Received my trees and am well satisfied. Sure nice trees.

GEORGE CRAWFORD.

VISIT OUR NURSERIES during growing, digging and storage season. We welcome you at any time.

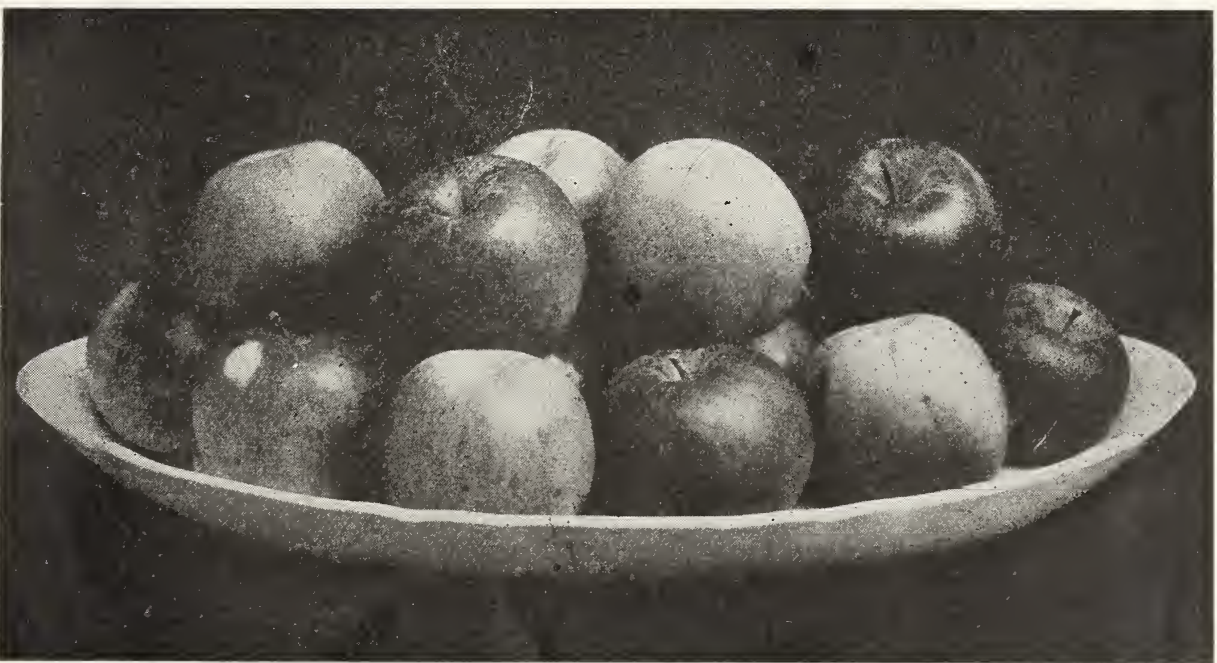




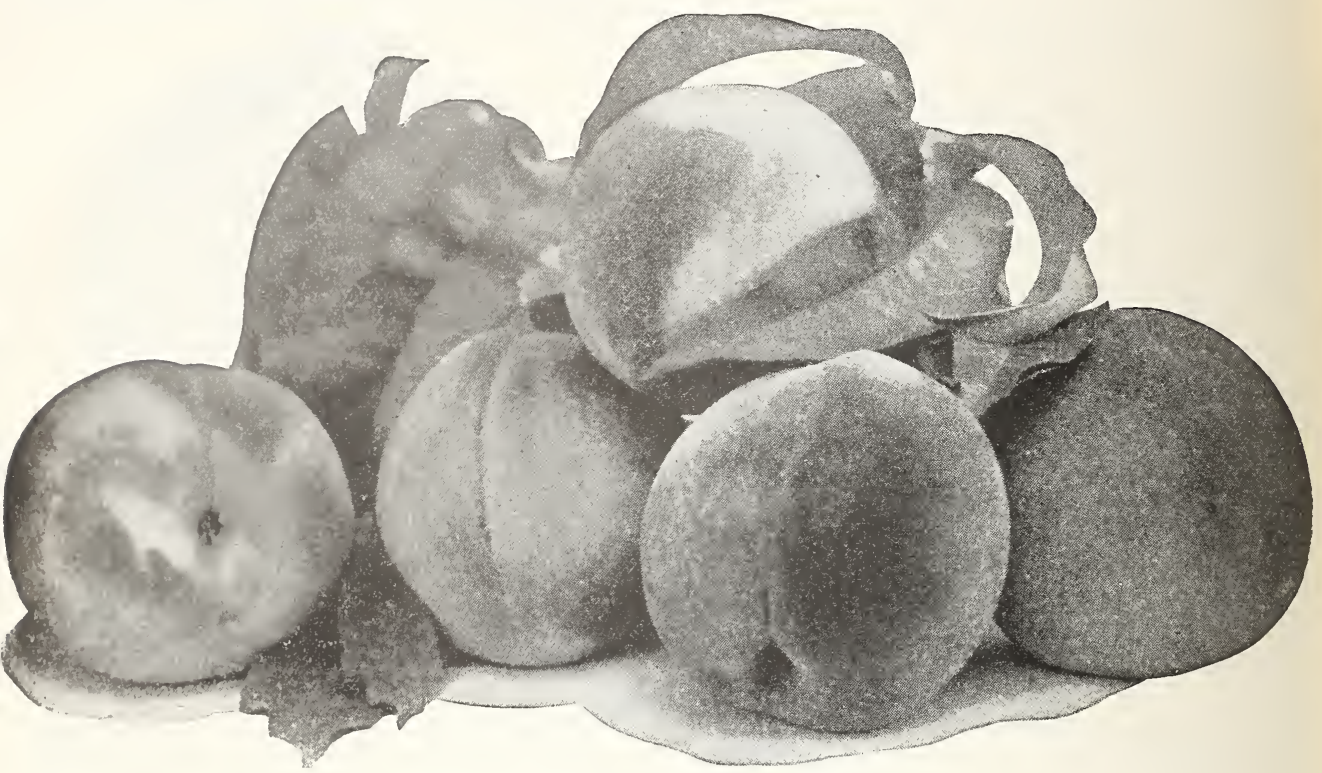

\section{Late Varieties}

GOLD DUST - Large yellow clingstone; juicy, productive and of best quality. September 1 st to 10 th.

HEATH CLING (White cling)-Large ob. long, creamy-white, slightly tinged with red in the sun; very tender, juicy, meltIng; very rich and luscious. September 15 th.

HENRIETTA (Levy) (Yellow Cling)-Mag. nificant yellow cling, large size, slightly covered with bright crimson; hardy, productive, always commands fancy prices. September 25 th.
OCTOBER BEAUTY (Yellow Cling)-Late yellow cling. Originated on the grounds of Judge Hugo Muench of St. Louis. We recommend it as the best late yellow cling.

PICQUET'S LATE (Yellow Free)-A variety of large size, yellow, with red cheek; flesh yellow. September.

RINGGOLD CLING (White Cling)-Much larger than Heath, and in every way an improvement on that popular kind. A very valuable peach. September.

STUMP (White Free)-Late freestone of very fine quality. September.

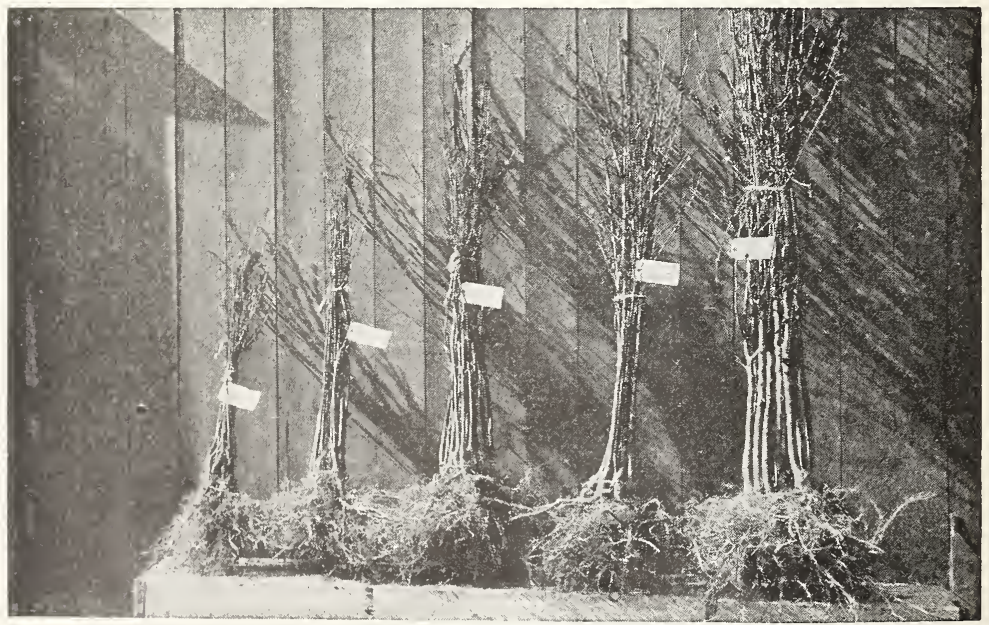

Showing Different Sizes of Peach Trees. 


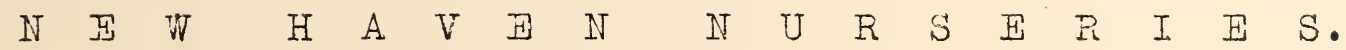

New Haven, Missouri, Feb. 20, 1930.

To Our Friends and Customers:--

Ve are enclosing herewith our Descriptive Catarof icr Spring 7930. We sincerely hope you will read it carefully and find many things of interest.

BAGBY GROWN Nursery Stozk has been 'Reliable for 58 Years' and every year we strive to give our customers the rery best stock, at the most reasonable prices. If you have purchased stock of us, you know it is good, but if you have never bought or seen any of our stock, it will be a pleasure to gife you the name of some one in your losality who kas bought. Ask him about our stock, and we are sure he will teli. you to order from the Nww HAVEIT IURSERIES.

When you buy stock from zxw us, you get it direct from the grower, and pay only one small profit. Wren you kuy from an ajent, you are paying him for the time it takes to sell Jour stock, and wlso for the time he lost on prospects t,o whom he did not soll.

Trusting to be favored with your early order, which shall have our very best attertion, for shipment, at, surh time as you wish, we cro,

$$
\text { Iours very time J, }
$$





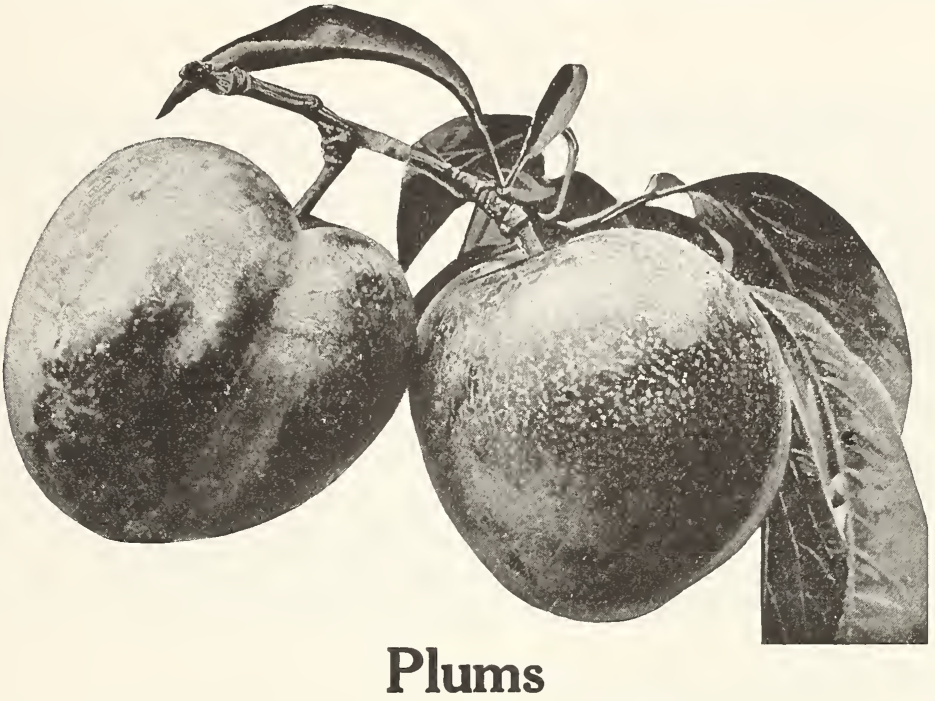

Each $10 \quad 100$

First class trees, 5 to $6 \mathrm{ft} . \$ 0.60 \$ 5.00 \$ 40.00$ First class trees, 4 to $5 \mathrm{ft}$. $.50 \quad 4.00 \quad 30.00$ First class trees, 3 to $4 \mathrm{ft} . \quad .40 \quad 3.00 \quad 20.00$ ABUNDANCE-A hardy, productive Japanese sort. Large, purplish-red; quality very best. Season, early in July.

BLACK BEAUTY-The best Japan sort we have ever grown. Large, very dark purple, almost black. Persimmon shape. Quality and size of Abundance. Originated with us.

BURBANK-Large, varying less in size than the other Japanese plums; it is nearly globular; clear cherry-red with a thin lilac bloom; flesh deep yellow, firm and meaty; tree vigorous and productive. Last of July.

GERMAN PRUNE-Very profitable and will succeed wherever Common Damson can be grown. Very large. We consider it the best of European sorts. August and September.
GONZALES-Large red plum. Midseason. HANSKA (Hansen Hybrid)-Good eating plum. Bright red.

RED JUNE-One of the largest Japanese varieties; ripens before Abundance. Tree upright, vigorous and hardy.

SHROPSHIRE DAMSON-A plum of fine quality, sprightly. In market it has com. manded nearly double the price of the Common Damson; enormously productive. Last of September.

WANETA (Hansen Hybrid)-Dark purplish red. Delicious flavor. Trees small.

WILD GOOSE-Large, rich, crimson, beauti. ful; flesh soft, melting delicious, with a full fruity flavor. Tree a strong grower, prolific.

For the Home Orchard, plant Abundance, Burbank, Black Beauty and Shropshire Damson.

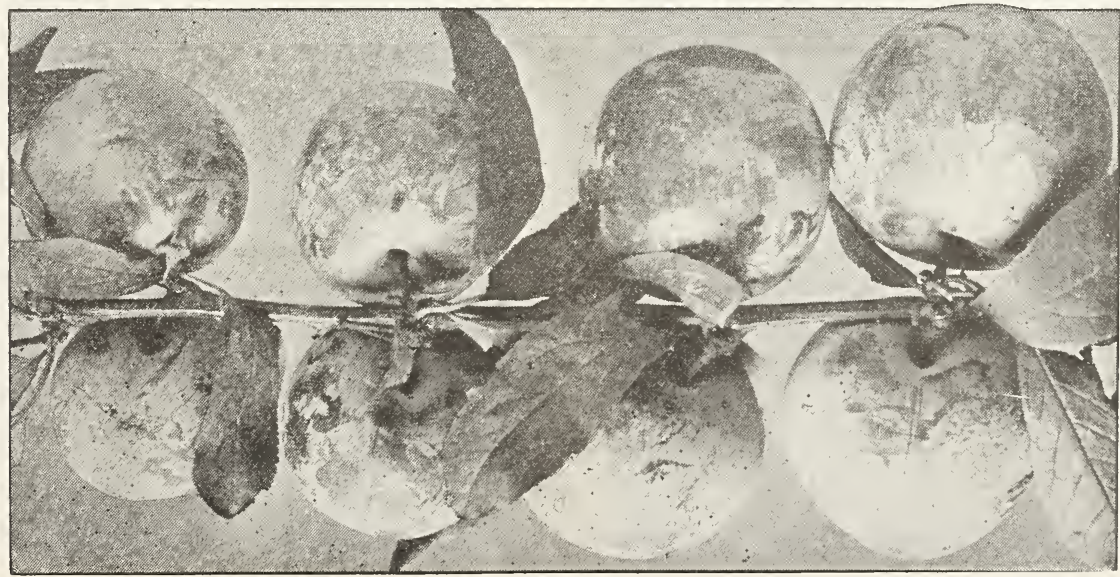

Burbank 


\section{Pears}

Our pears are especially clean, smooth and well rooted, grown on $\mathrm{XX}$ French imported stocks.

$\begin{array}{lll}\text { Each } & 10 & 100\end{array}$

Leading sorts, first class,

5 to 7 feet, 2 years.....\$0.75 $\$ 6.50 \$ 50.00$

Leading sorts, 4 to 5 feet,

2 year ................ .60 $5.00 \quad 35.00$

Leading sorts, 3 to 4 feet,

1 year, very fine...... $.50 \quad 4.00 \quad 30.00$

For Kieffer in Quantities, Write for Special Low Prices.

\section{Summer Pears}

BARTLETT-Large, skin very thin, clear lemon-yellow, with soft blush on the sunny side; flesh white, buttery, very juicy and highly flavored. The best summer pear in existence for quality.

KOONCE-The handsomest, best and most valuable; very early pear; tree vigorous, upright grower, free from blight; magnificent foilage, which it retains late in the season; fruit medium to large; skin yellow, does not rot at the core, juicy, sweet. Is an excellent shipper.

8ECKEL (Little Sugar Pear)-Small, rich, yellowish brown with bright red cheek. Juicy, buttery and melting.

Lafayette Co., Mo., April 6, 1929.

The trees arrived in good shape and are extra good.

\section{G. F. OBERHELMAN.}

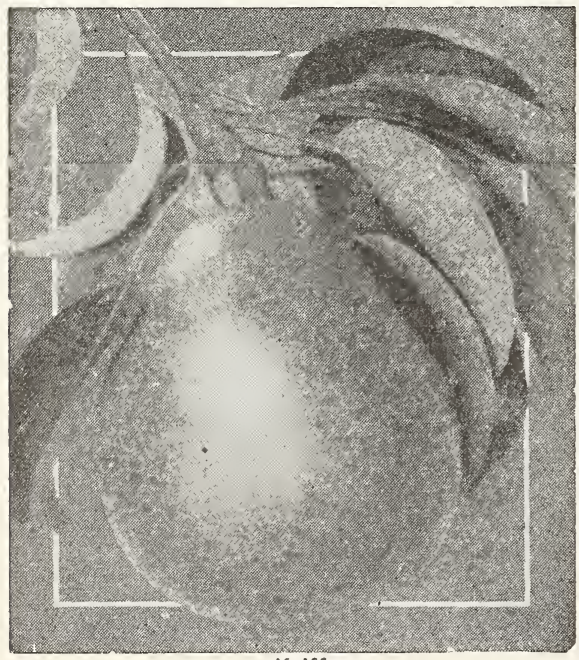

Keiffer

\section{Autumn Pears}

FLEMISH BEAUTY-Large, b e a u $t$ if $u l$, juicy, melting, rich and fine; strong grower and good bearer; hardy everywhere. September and October.

GARBER - Originated in Pennsylvania. Fruit is large and beautiful; color bright yellow, with red; juicy and good; delicious canned.

KIEFFER-Tree a remarkable grower, with so vigorous a constitution that it rarely blights. Fruit of fine size, rich color and good quality. Brings high prices in competition with other varieties. Best when picked at maturity and house-ripened. October and November.

Wayne Co., Mo., Nov. 16, 1929. About nineteen years ago I bought my first trees and you sure sent me good trees, and true to name and that is why I still buy from you.

D. R. BLACKNELL.

Wayne Co., Mo., Nov. 23, 1929.

The trees came in due time and I certainly do thank you very much for such a nice lot of trees.

D. R. BLACKNELL.

Boone Co., Mo., April 23, 1929.

The fruit trees I ordered arrived in good condition and are fine healthy trees. I had ordered trees from your nursery before and was pleased in every way.

MRS. J. R. ANTHONY.

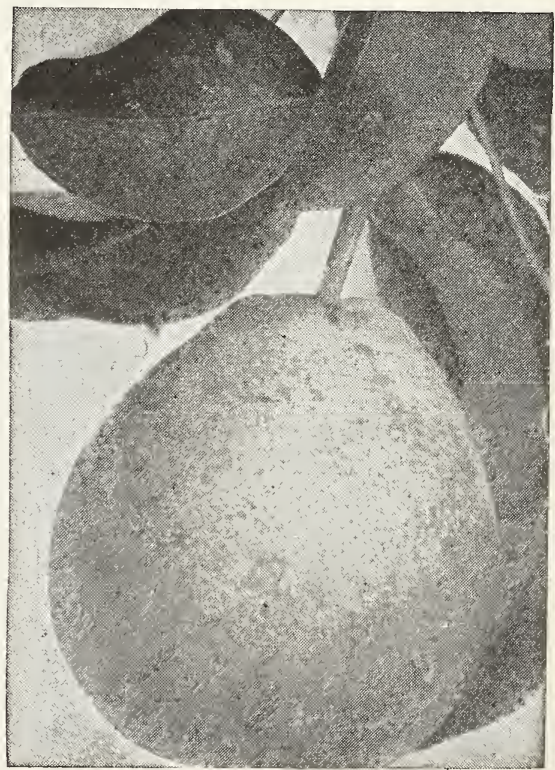

Bartlott 


\section{Cherries}

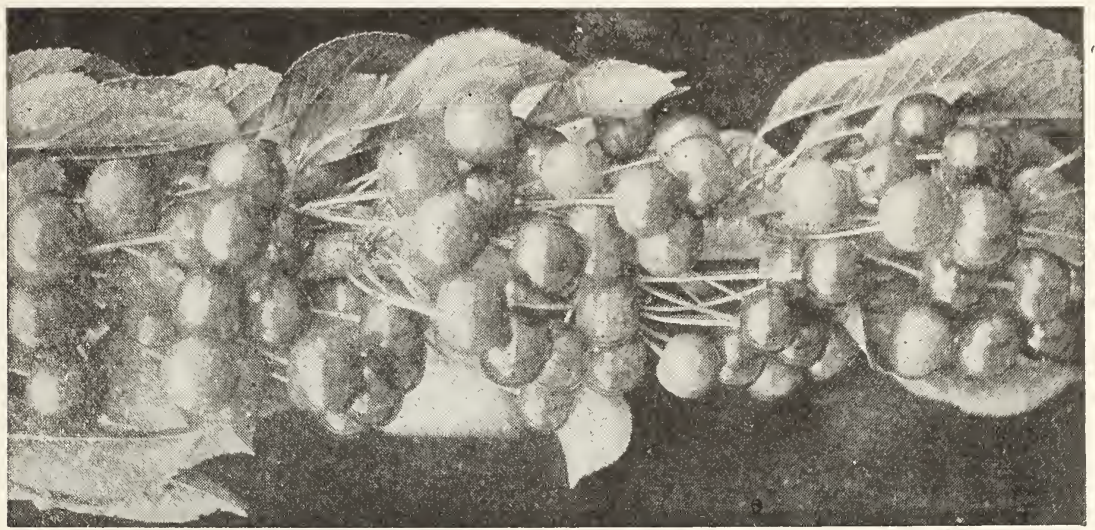

There are few more desirable fruits than Cherries, and they can be grown for market with great profit. Along the street or avenue as ornamentals; they are strong, vigorous growers, with large, glossy leaves and open, spreading heads, making a fine shade. Cherries thrive in almost any well-drained soil. The fruit is equally delicious whether eaten from the tree or preserved, and it will always find a ready market at profitable prices.

Our Cheriy trees are all budded on Imported French Mahaleb stock. They have fine roots and nice heads. All well rooted and will be graded full size indicated, and up.

\section{Each $\quad 10 \quad 100$}

Leading sorts, extra select, 2-year, $41 \frac{1}{2}$ to 6 feet.....\$1.00 $\$ 8.50 \$ 70.00$

Leading sorts, first-class, 2-year, $3 \frac{1}{2}$ to 5 feet.... $\quad .857 .50 \quad 60.00$

Leading sorts, first-class, 1-year, 3 to 4 feet...... .60 $5.00 \quad 40.00$

BLACK TARTARIAN-Sweet. Large size, meaty and good. Productive. Last of June.

ENGLISH MORELLO-Medium to large, blackish-red; acid; juicy. Very productive. Short lived. July.

EARLY RICHMOND (Kentish Virginian or Early May)-Medium size; red; melting, juicy, sprightly, acid flavor. This is one of the most valuable and popular of the acid cherries, and is exceedingly productive. First of June.

GOV. WOOD-One of the best sweet cherries, very large, white with pink cheek. Juicy, rich and delicious. Tree healthy and a great bearer. May and June.
MONTMORENCY-One of the finest acid cherries; tree very hardy and an immense bearer; commences to fruit while young and is loaded annually thereafter with fine crops; fruit of good size, fine flavor, and of bright, clear, shining red; valuable everywhere, especially for Northern latitudes; larger than Early Richmond, and fully ten days later. Season, end of June.

MAGANN-A sweet cherry. Fruit large, almost black when fully ripe, growing in large clusters. It will pay you to include some of these in your order for other stock.

For Middle West We Suggest as Best Com. mercial Sorts in Cherry-Richmond Montmorency, Magann

Jackson Co., Mo., April 16, 1929.

Received trees and small fruit in fine shape. Am well pleased.

\section{W. L. JACKSON}

Buchanan Co., Mo., Nov. 19, 1929.

I received my order in fine condition. I sure was pleased with the trees and shrubbery. They could not have been better.

\section{G. A. McVEY.}

Van Buren, Ia., April 25, 1929.

I wish to acknowledge receipt of fruit trees ordered of you. I believe they are as good trees as could be produced anywhere regardless of price. Many thanks for the gratis trees. You surely give full value.

CLYDE KERR. 


\section{Apricots}

Each $10 \quad 100$

4 to 6 feet, extra select...\$1.00 \$8.50 \$70.00

3 to 4 feet, first-class.... $.75 \quad 6.00 \quad 50.00$

EARLY GOLDEN-Medium. Golden-yellow. Moderately juicy and sweet. First of July.

MOORPARK-One of the largest. Orange with red cheek. Firm and juicy. Very productive. July.

ROYAL-Large. Light yellow with red cheek. Rich and juicy. Last of July.

\section{Quince}

Each 10

3 to 4 feet, 2 year, extra select.. \$\$1.00 $\$ 9.00$

CHAMPION-Large; oval; firm and of excellent quality. Ripens late and good keeper.

ORANGE-Large; round; bright golden-yellow. Fine for preserving. Good market sort.

\section{Nut Trees}

BUTTERNUTS-Large shapely tree. Nuts are long with hard black shells. Kernels very sweet and rich Each 10 3 to 4 feet,..............\$0.60 \$5.00

PECANS (Seedlings)-From selected seed. Trees are long lived. Quite hardy and productive Each 10 3 to 4 feet, 2-year......... \$0.80 $\$ 7.00$ Budded, 5 to 6 feet......... 1.5012 .50

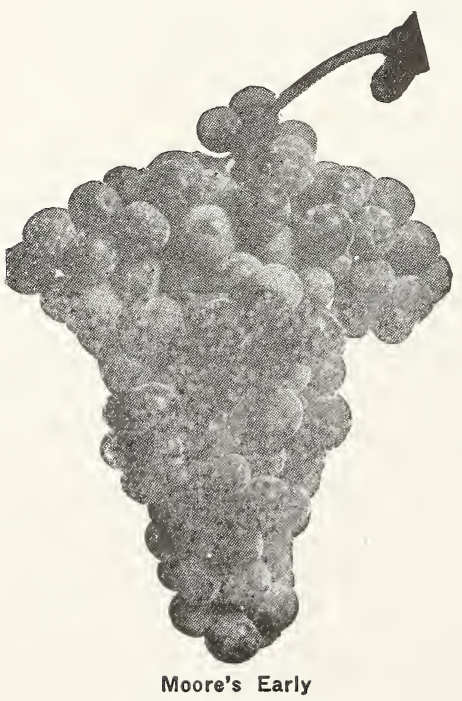

To cover season for succession, plant Moore's Early, Nlagara, Concord, Worden, Catawba.

For Arbor, plant strong-growing sorts: Norton's Virginla, Concord, Nlagara.

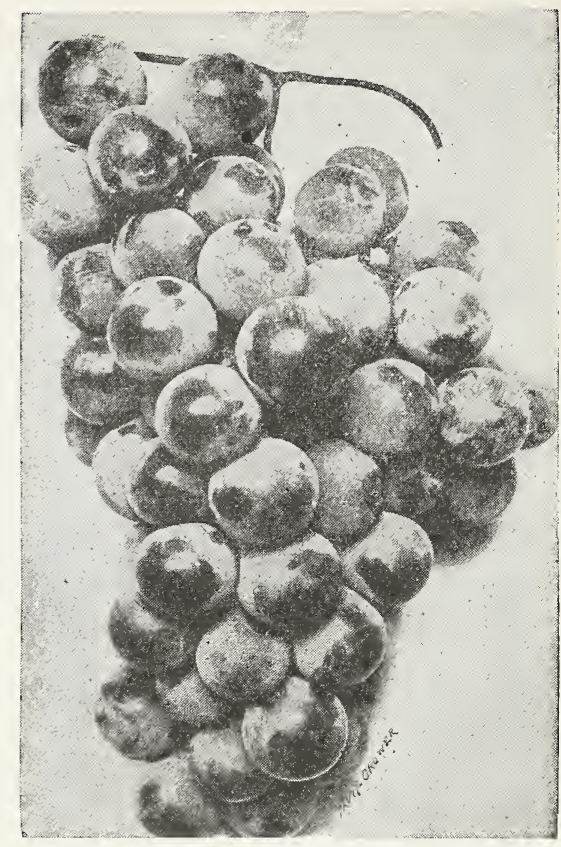

Concord

\section{Grape Vines}

\author{
2 yr., No. 1
}

CONCORD-Black. The standard black grape. Largely planted in vineyards and gardens. It is firm; a good keeper and shipper. Fine for table use and for grape juice. Each $10 \quad 100$ Price .............. \$0.20\$1.50\$8.00

MOORE'S EARLY-Black. Ripens early. Large sweet and good. Each $10 \quad 100$ Price ............. \$0.30 \$2.00\$15.00

NORTON'S VIRGINIA-Black, Clusters medium; berry small. Very juicy. Best variety for arbor planting. Late.

$$
\text { Each } 10 \quad 100
$$

Price ..............\$0.35 \$3.00\$28.00

WORDEN-Black. Bunch and berries large. Excellent quality. Vine a strong, healthy and vigorous grower. Each $10 \quad 100$ Price .............\$0.25 \$1.50\$12.00

CATAWBA-Red. Thin skin and tender flesh. Very sweet and of fine quality. Each $10 \quad 100$ Price ............. \$0.20 \$1.50\$12.00

DELAWARE-Red. Bunch small but very productive. Very sweet and juicy.

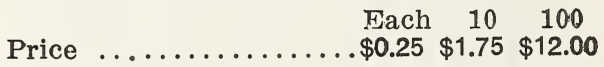

NIAGARA-White. The standard white grape. Bunch and berry large and well formed. Juicy, without much pulp. Flavor the very best Each $10 \quad 100$ Price ............\$0.25 \$1.50\$12.00 


\section{Small Fruits and Berries}

\section{Strawberry Plants}

Prices of Strawberry Plants, for spring shipment only: Selected plants $\$ 1.25$ per 100 , by parcel post, prepaid. $\$ 6.00$ per 1,000 , by express, f. o. b., New Haven, Mo.

Large orders must be sent by express. Small orders carry safely by mail. They do not carry well by freight.

AROMA (Per.)-Plants large, very vigorous and perfectly healthy. Fruit large to very large, roundish, smooth and perfect in form, of a beautiful bright glossy red in color, very firm, and of excellent quality. Late.

SENATOR DUNLAP (Per.)-A well-tested, wonderfully productive variety. Fruit of good size, regular form, beautiful bright red, glossy, firm, splendid keeper and shipper, excellent quality. Mid-season.

DR. BURRILL (Per.)-Dark red berry. Ripens with Senator Dunlap, but season much longer.

GIBSON (Per.)-Large, even shape; glossy, dark red. Firm and high quality, ripening over a long season. Medium to late.

PREMIER (Per.)-Early. Large, bright glossy berry. Very productive

\section{Dewberry $\quad 10 \quad 100$}

Price ...................\$0.60 $\$ 4.00$

LUCRETIA-Large berry. Early. Plant strong grower. Very productive.

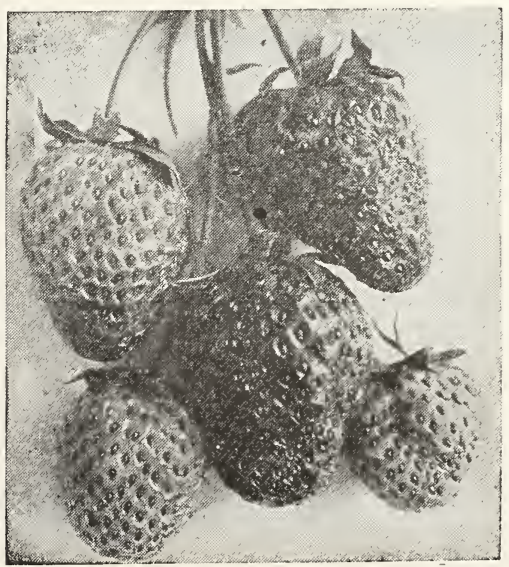

Strawberries

\section{Black Raspberry}

$10 \quad 100$

Price ................. \$0.50 $\$ 3.00$

CUMBERLAND-Black. Mid-season. The best blackcap.

KANSAS-Black. Early. A strong vigorous grower. Berries jet black and almost free from bloom.

PLUM FARMER-Black. Ripens very early and quickly.

\section{Red Raspberry}

$10 \quad 100$

Price .................\$0.50 \$4.00

CUTHBERT-Red. Very large and firm. Strong grower. Hardy.

MILLER-Rod. Medium size. Early. Hardy and productive.

\section{Blackberry}

EARLY HARVEST-The earliest blackberry. Very valuable for market. Strong, upright grower and very productive.

$10 \quad 100$

Price ................\$0.60\$4.00

MERSEREAU-Early. Large berry with small seed. Very strong grower.

Price....... .000

$\begin{array}{ll}10 & 100 \\ \$ 0.60 & \$ 5.00\end{array}$

SNYDER-Late. Extremely hardy. Very productive. Sweet and juicy.

Price ............... 10100

\section{Gooseberries}

Each $\quad 10 \quad 100$

Two-year, No. 1,.......\$0.25 \$2.00\$16.00

DOWNING-Fruit large and of fine appear. ance. Bush a good grower and heavy cropper. Pale green color.

HOUGHTON-Heavy producer. Fruit small Fine quality. Pale red.

\section{Currants}

Each 10

Two-year, No. 1............\$0.25 \$2.00

FAY'S PROLIFIC-Fruit large. Bright red. Excellent flavor.

RED DUTCH-Berries medium. Bright red. Good flavor.

\section{Rhubarb}

MYATT'S LINNAEUS-Early. Large stalks of bright red color.

Each $10 \quad 100$

Price ..............\$0.10 \$0.80\$6.00

\section{Asparagus}

WASHINGTON-1 year.

Price...............\$2.00 per 100 


\section{Shade and Ornamental Trees}

CATALPA BUNGEI (Umbrella Catalpa)Grafted on straight stems, it makes an umbrella-shaped top without pruning. Perfectly hardy, and flourishes in all soils and climates.

Each 10

5 to 7 feet.............. \$1.00 $\$ 8.00$

4 to 5 feet....................... $80 \quad 8.00$

3 to 4 feet................70 5.00

CATALPA (Speciosa)-Hardy Catalpa. Has very large, broad leaves and fragrant purplish white blossoms. Excellent for post timber as it is very resistant to rot. Each 10

6 to 8 feet................ $\$ 0.50 \$ 4.00$

ELM (American)-A native tree of large size. Wide spreading head and graceful drooping branches. A hardy grower. One of the best park and street trees.

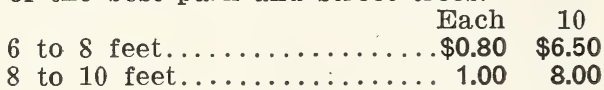

MAPLE (Soft) - A native tree of very rapid growth. Hardy everywhere and easily transplanted. Leaves are finely cut, bright green on upper and whitish on lower side.

Each 10

8 to 12 feet............... \$1.00 $\$ 8.00$

6 to 8 feet................. $.75 \quad 6.00$

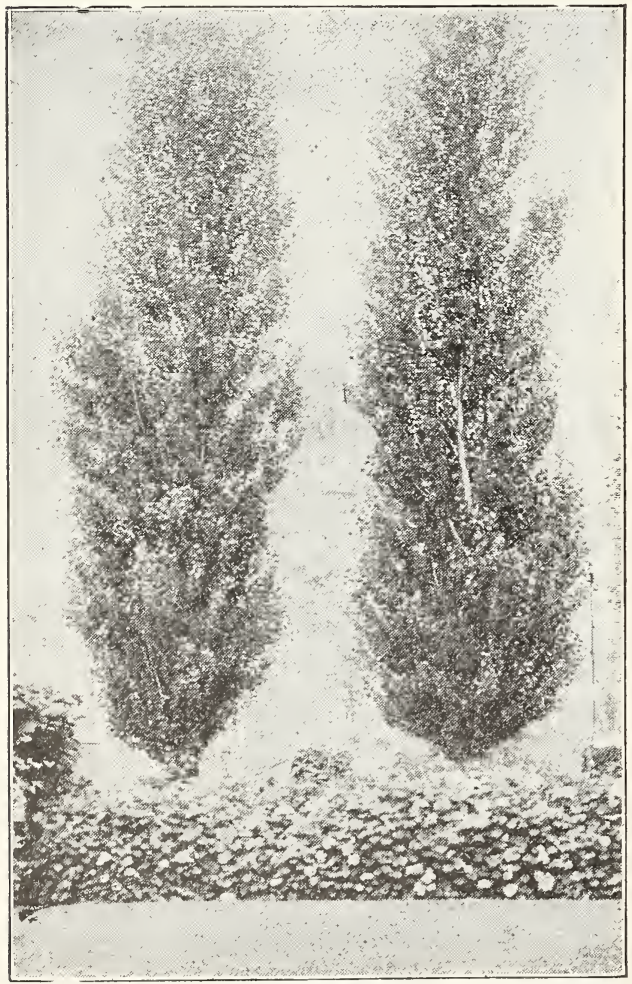

Lombardy Poplar

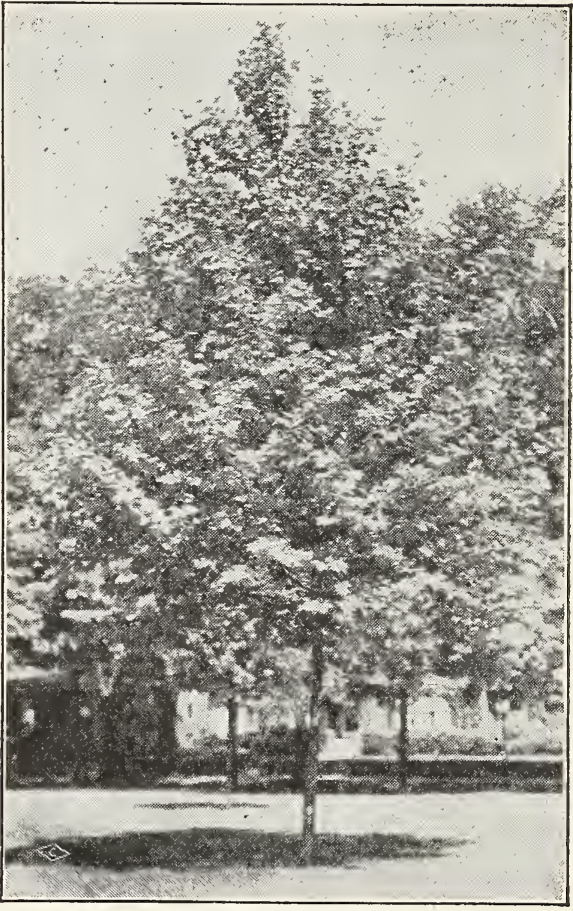

Soft Maple

POPLAR (Lombardy)-A tall, rapid grower. Always makes a striking feature in any landscape. For tall screens and backgrounds, this tree is admirable.

Each 10

6 to 8 feet............... $\$ 0.60 \$ 5.00$

PUSSY WILLOW-Very popular for ornamental purposes because of the attractive catkins formed on the branches early in the Spring.

Each 10

3 to 4 feet..............\$0.60 $\$ 5.00$

RUSSIAN MULBERRY. Each 10

4 to 6 feet..............\$0.60 $\$ 5.00$

SYCAMORE-One of the tallest of our native trees. Very shapely and much admired because of its white spotted bark. One of the best trees for cities.

Each 10

5 to 6 feet.............. $\$ 1.00 \$ 8.00$

TULIP TREE-A tall, robust tree of magnificent appearance. Leaves of unusual form. The blossoms are tulip-like in shape.

Each 10 5 to 6 feet............... $\$ 0.80 \$ 7.00$ 


\section{Ornamental Shrubs}

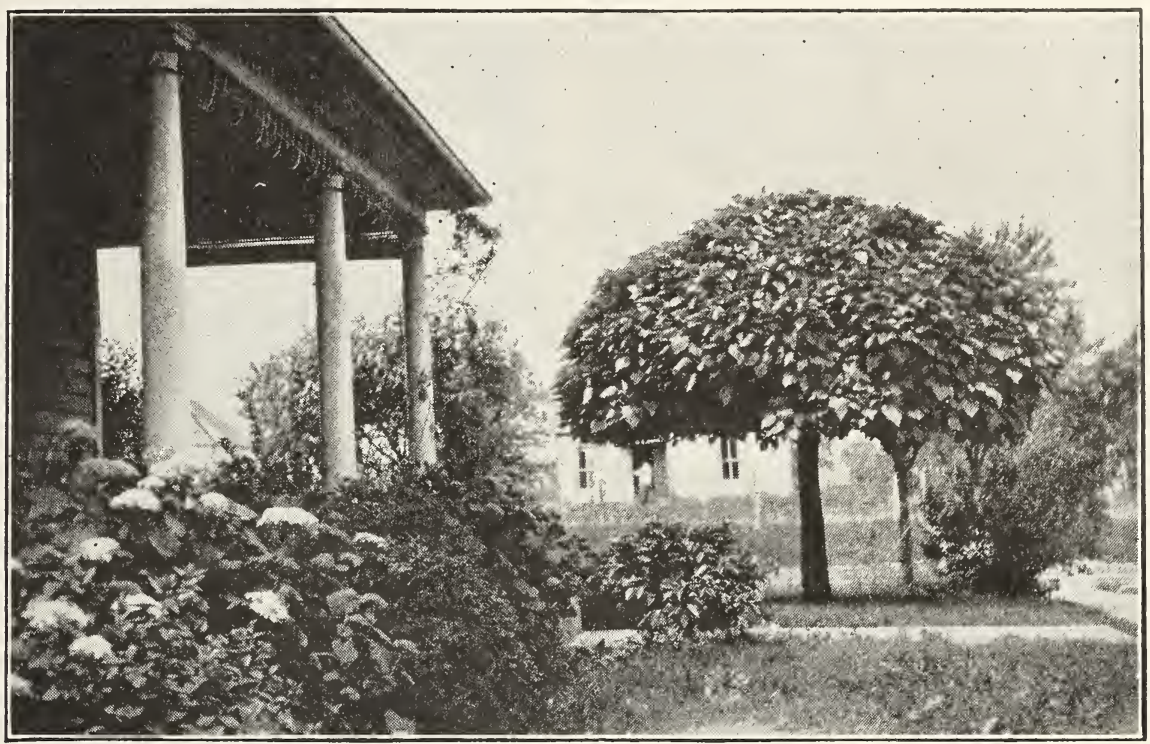

\section{It's Not a Home Until It's Planted}

ALTHEA (Hibiscus, or Rose of Sharon)Handsome, late, summer-flowering shrub. Assorted colors. Each 10

2 to 3 feet.............\$0.40 $\$ 3.50$

BARBERRY (Thunbergii) - A very valuable low growing shrub; perfectly hardy. Small green leaves changing to red in fall. Twigs thorny and covered with red berries in the Fall and Winter.

Each 10

18 to 24 ih.............. \$0.35 $\$ 3.00$

BARBERRY (red leaf)-Similar to the green leaved Barberry but the foliage is of a rich, lustrous, bronzy-red, which becomes even more brilliant as the season advances.

18 to 24 inches........... $\$ 0.75 \quad \begin{array}{cc}\text { Each } & 10 \\ \$ 6.00\end{array}$

BUTTERFLY BUSH-Very fast growing shrub; is valued for its dark purple flowers, borne in long spikes on tip end of each branch, in late July and August.

Each 10

2 to 3 feet.............\$0.40 \$3.50

COTONEASTER-A handsome fruiting shrub, with brilliant foliage. Grows well in any well drained soil, but needs plenty of sunlight.

18 to 24 inches, balled and burlapped,

each ..................\$1.50

DEUTZIA (Crenata)-Foliage light green; flowers double white, outside tinged with rose.

2 to 3 feet............ Each $\quad 10$

DEUTZIA (Pride of Rochester)-Flowers pure white, double, tinged with pink. Profuse bloomer. Tall shrub. Each 10 2 to 3 feet.............\$0.40 $\$ 3.50$

FORSYTHIA (Golden Bell)-A spreading bush with dark, shining foilage. Deep yellow flowers appear before the leaves. Each 10 3 to 4 feet............\$0.50 $\$ 4.50$

HYDRANGEA (Arborescens Grandiflora) (Hills of Snow)-Blossoms large, snow white. Blooms from June to September. Each 10 2 to 3 feet...............\$0.45 $\$ 4.00$

HYDRANGEA (Paniculata Grandiflora)Blooms early in August and continues until freezing weather. White, turning to pink. Each 10

2 to 3 feet............\$0.50 $\$ 4.50$

LILAC (White)-When planted with purple makes a very desirable contrast.

Each 10

2 to 3 feet............\$0.60 $\$ 5.00$

LILAC (Purple)-A good grower. Flowers and young wood fragrant. Each 10 2 to 3 feet.............\$0.60 $\$ 5.00$

MOCK ORANGE (Philadelphus)-Flowers white. Deliciously perfumed. Flowers ro semble orange blossoms. Each 10 2 to 3 feet..............\$0.40 $\$ 3.50$ 


\section{Ornamental Shrubs-Continued}

PRIVET (California)-A vigorous-growing variety of fine habit; thick; glossy. The finest of ornamental hedge plants.

3 -yr. No. $1-3$ to $4 \mathrm{ft}$., extra

$10 \quad 100$

heavy .............. \$1.25 $\$ 10.00$

2 -yr. No. $1-2$ to $3 \mathrm{ft}$., heavy.. $\quad 80 \quad 7.00$

2-yr.-18 to 24 inches, first

class ....................60 $\quad .00$

PRIVET (Ibolium)-A new variety. Similar to California Privet in growth and appear. $\begin{array}{lll}\text { ance. Perfectly hardy. } & 10 & 100\end{array}$ 2 -yr. -2 to 3 feet..........\$0.80 $\$ 7.00$ 2 -yr. -18 to 24 inches......... $\quad .60 \quad 5.00$ SNOWBERRY (White)-An old-time shrub. Delicate pink flowers which produce clusters of pure white berries, which remain practically all winter. Each 10 2 to 3 feet..............\$0.40 $\$ 3.00$ SNOWBERRY (Red) (Indian Currant) (Coral Berry)-Berries red, somewhat smaller than White Snowberry. Each 10 2 to 3 feet................\$0.30 $\$ 2.50$

SPIREA (Anthony Waterer)-Flowers bright red in flat clusters. Blooms nearly all summer. Dwarf variety, growing 2 to $3 \mathrm{ft}$. Each 10 18 to 24 inches............ \$0.50 $\$ 4.50$

SPIREA (Billiardi)-Bears pink flowers in spikes in July and August. Upright grower.

$\begin{array}{rr}2 \text { to } 3 \text { feet............. } \$ 0.40 & 10 \\ \$ 3.50 & \end{array}$

SPIREA (Douglasi)-Upright in growth, with reddish-brown branches and narrow oblong leaves. Bears spikes of beautiful rose colored flowers.

Each 10

2 to 3 feet............... $\$ 0.40 \$ 3.50$

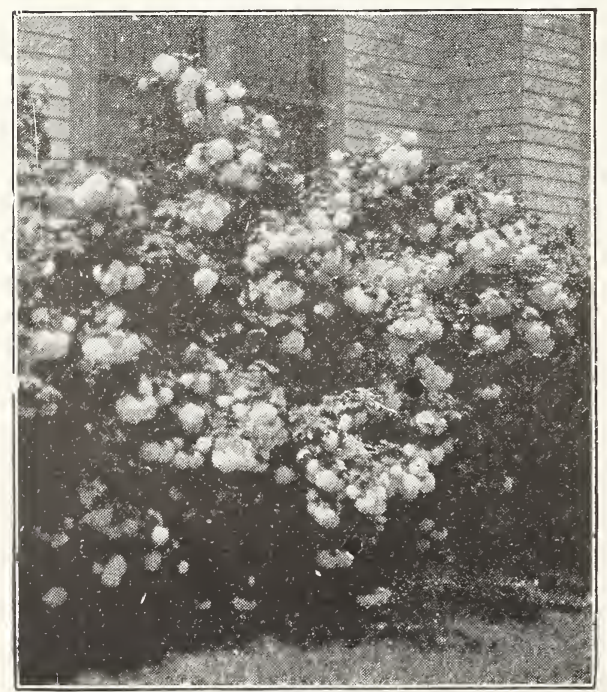

Snowball

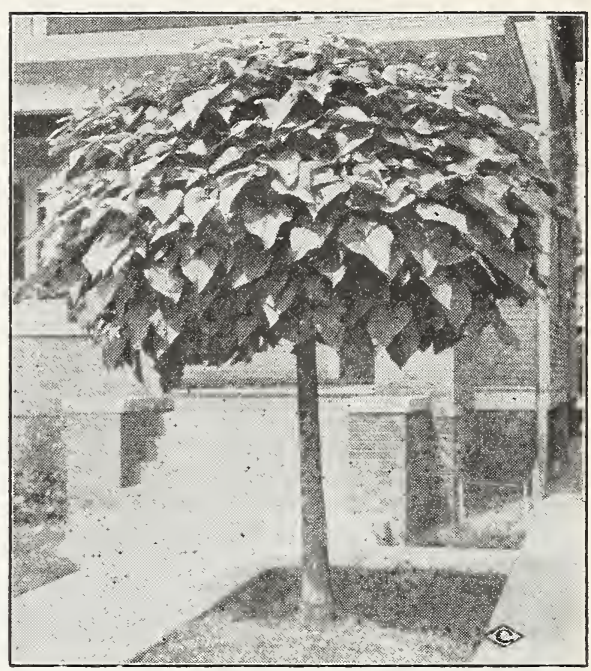

Catalpa Bungei (See Page 14)

SPIREA (Prunifolia) (Bridal Wreath)-Very graceful shrub. Is covered with small white flowers in April. Foliage bright green turning to orange red in fall.

2 to 3 feet........... Each $\quad \begin{aligned} & 10 \\ & \$ 0.45\end{aligned}$

SPIREA (Van Houtti)-An extremely graceful shrub with long, drooping branches completely covered with clusters of white flowers in May and June. Makes a beautiful hedge. Perfectly hardy.

$$
\text { Each } 10 \quad 100
$$

2 to 3 feet............\$0.30 $\$ 2.50 \$ 20.00$

SNOWBALL (Common)-Flowers white, in clusters; very attractive. May to June.

Each 10

2 to 3 feet............... $\$ 0.60 \$ 5.00$

TAMARIX (Africana) - Beautiful feathery foliage, light pink flowers. A tall graceful shrub growing 8 to 12 feet.

2 to 3 feet............ Each $\quad \begin{aligned} 10 \\ \$ 3.00\end{aligned}$

WEIGELIA (Floribunda)-Flowers are very numerous and are a beautiful crimson when fully opened. A tall growing shrub.

$$
2 \text { to } 3 \text { feet............. } \$ 0.50 \quad \begin{aligned}
& 10 \\
& \$ 4.00
\end{aligned}
$$

WEIGELA (Rosea)-An elegant shrub, with fine rose-colored flowers. Erect, compact growth. Blooms in June Each 10 2 to 3 feet............... \$0.50 $\$ 4.00$

WEIGELIA (Eva Rathke)-A large upright shrub with crimson trumpet shaped flowers.

Each 10 2 to 3 feet............... \$0.50 $\$ 4.00$ 


\section{Evergreens}

\section{BALLED AND BURLAPPED}

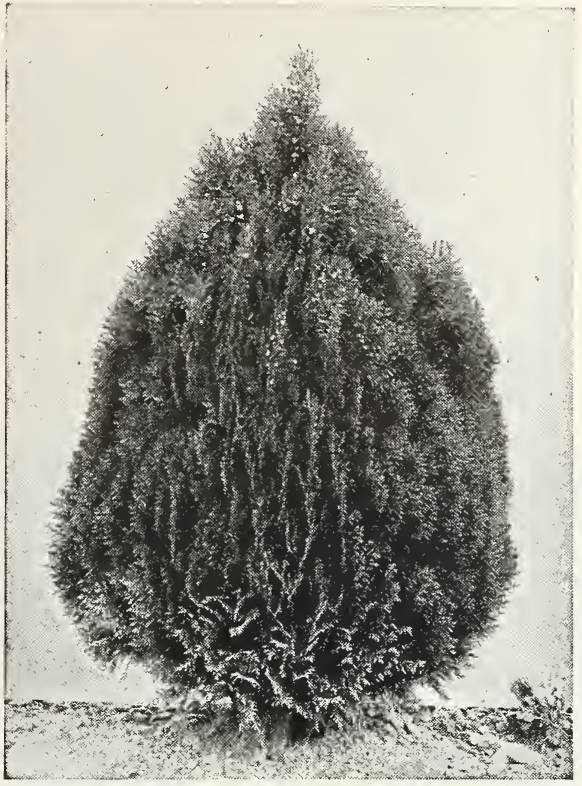

American Arbor Vitae

AMERICAN ARBOR VITAE-One of the most popular evergreens. Very easy to transplant, and is very attractive as a hedge plant. Stands trimming better than any other evergreen.

2 to 3 feet..............\$3.00 Each

CHINESE PYRAMIDAL ARBOR VITAEA densely columnar type, admirable for ornamental purposes. Very hardy.

2 to 3 feet.............. \$3.50 Each

DOUGLAS FIR-Popular for its hardiness and great beauty; large conical form; branches spreading horizontally.

2 to 3 feet.............\$4.25 Each

PFITZER JUNIPER-One of the handsomest of the semi-drawf Junipers. Its habit of growth, its pendulous branches and attractive foliage are strikingly beautiful.

18 to 24 inches............\$5.00 Each
MUGHO PINE-Very dwarf in habit, having a ball like form that is greatly admired. Excellent in foundation groups or as individual specimens.

12 to 15 inches............\$4.00 Each COLORADO BLUE SPRUCE-One of the most valuable evergreens grown. Becomes a tree of upright conical form. Foliage is a bluish green.

18 to 24 inches............\$7.00 Each

NORWAY SPRUCE-Becomes a tall tree of majestic conical shape. One of the most rapid growing and shapely of the tall dark green spruces.

2 to 3 feet...............\$3.00 Each

WHITE SPRUCE-A very hardy evergreen. Compact upright grower, retaining its branches to the ground. Elegant silvery foliage. Long lived.

2 to 3 feet.............\$4.25 Each

Cooper Co., Mo., Nov. 18, 1929.

Trees received promptly and am well pleased. CHAS. E. LAMM.

Lafayette Co., Mo., Nov. 16, 1929.

Trees arrived yesterday and are fine. MRS. J. P. LOHOEFENER.

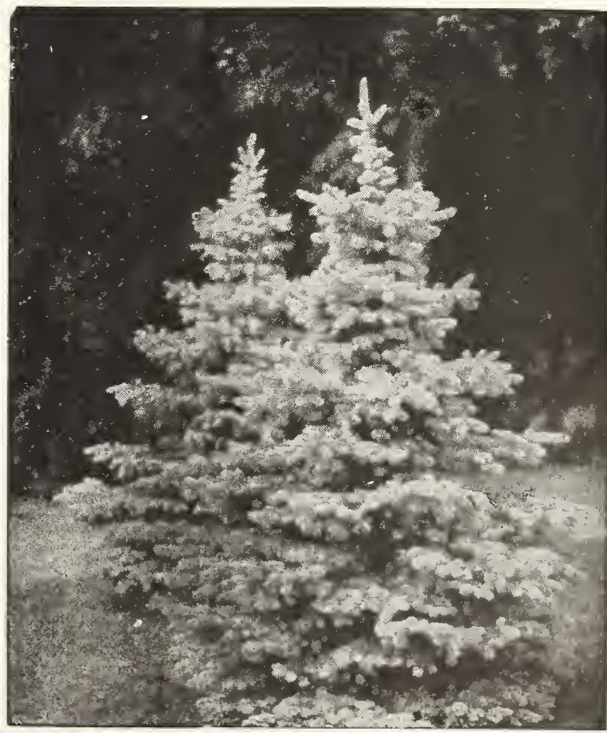

Colorado Blue Spruce 


\section{Climbing Vines}

BOSTON IVY-A very hardy vine with foliage turning brilliant red in autumn. Clings very tightly to any wall.

Each 10 2-yr. No. 1..............\$0.50 \$4.00 CLEMATIS PANICULATA-Fast grower. White flowers are borne in clusters completely covering the foliage. September.

Each ......\$ \$0.40 10.....\$3.50

\section{Dahlias}

For best results plant Dahlias late in June or early in July. Cultivate thoroughly.

AUTUMN PERFECTION (Peony)-Copper. Each 10

Price ............... \$0.35 $\$ 2.50$

CALIFORNIA PEONY-Yellow with pink shading. $\quad$ Each 10

Price ................ \$0.35 \$2.50

DR. TEVIS (Decorative)-Salmon Rose.

Each 10

Price ................ \$0.40 $\$ 3.50$

MARY QUEEN OF SCOTS (Decorative)-

Delicate pink. Each 10

Price ................. \$0.40 $\$ 3.00$ MINA BURGLE (Decorative)-Bright red. Each 10

Price ................. \$0.35 $\$ 2.50$ SOUVENIR DE MILWAUKEE (Single)-

Purplish. Each 10

Price ................ \$0.30 \$2.00 JERSEY BEAUTY (Decorative)-Pink.

Each 10

Price ...............\$0.60 \$5.00 JACK ROSE (Decorative)-Pink.

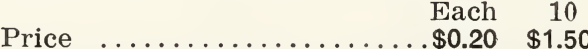

JACK ROSE (Decorative)-Red.

Price $\ldots \ldots \ldots \ldots \ldots \ldots \ldots . \$ 0.20 \quad \begin{array}{ll}\text { Each } & 10 \\ \$ 1.50\end{array}$

QUEEN VICTORIA (BaII)-Yellow.

Each 10

Price .................\$0.15 $\$ 1.00$

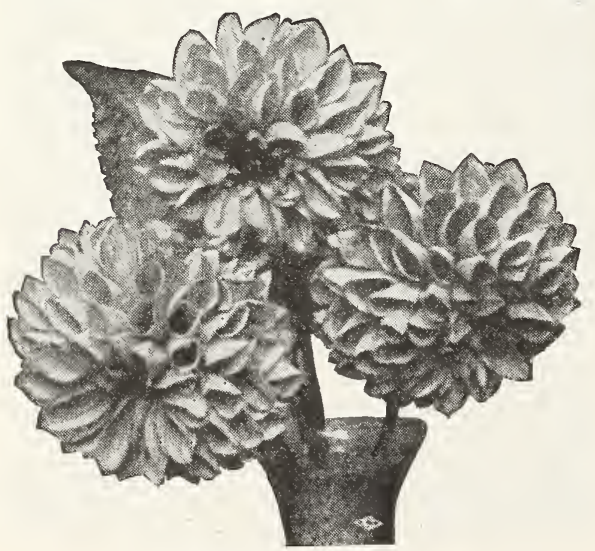

Decorative Dahlias

\section{Roses}

\section{Hybrid Perpetuals and Teas}

Cut back severely when planted, for best results.

Each 10

2-year, extra select.........\$0.60 \$5.00

KAISERIN AUGUSTE VICTORIA-H. T. Pure White.

HELEN GOULD-H. T. Watermelon-red.

PAUL NEYRON-H. P. Deep rose.

RADIANCE-H. T. Pink.

RADIANCE-H. T. Red.

GRUSS AN TEPLITZ-H. T. Crimson.

SUNBURST-H. T. Yellow.

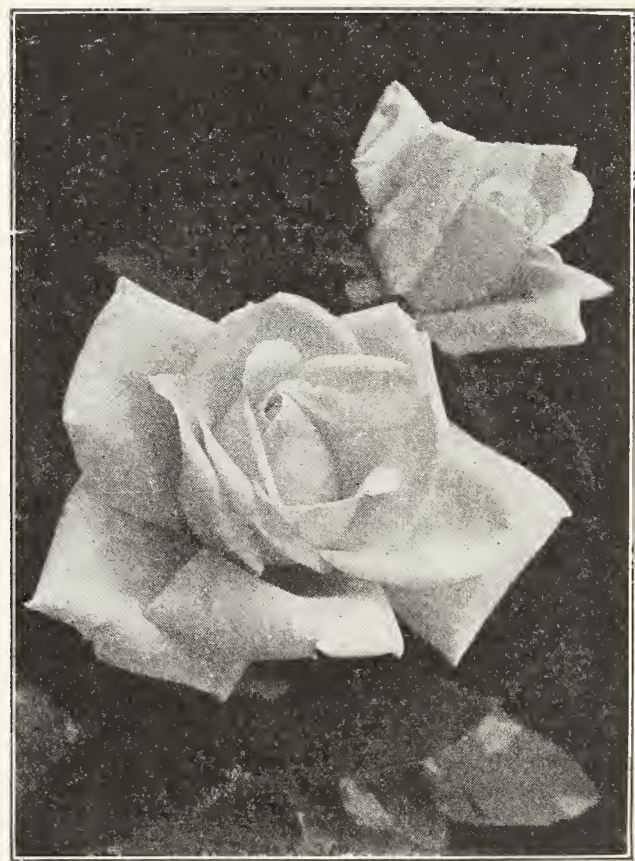

\section{Climbing}

Each 10

2-year, extra select..........\$0.50 \$4.00

CLIMBING AMERICAN BEAUTY-Pink.

SILVER MOON-White.

CRIMSON RAMBLER.

DOROTHY PERKINS-Pink.

PAUL'S SCARLET.

DR. VAN FLEET-Pink.

AMERICAN PILLAR-Pink. 


\section{ORDER BLANK \\ KEEP A COPY OF YOUR ORDER \\ NEW HAVEN NURSERIES \\ NEW HAVEN, Franklin County, Mo.}

Name

Mr., Mrs. or Miss. Write Plainly

Post Office

street, P. O. Box or R. F. D.

County

State

Express or Freight Office

If different from Post Office.

Forwarded by ............................

Date

About.

We use the greatest care possible to have our stock true-to-name, and should any prove not true we stand ready to replace it free of charge, or to refund the purchase price, but it is mutually agreed hetween the purchaser and ourselves that we shall not at any time be held responsible for any sum retween the purchaser and ourselves that we shall not
greater than the amount originally paid for gaid otock.

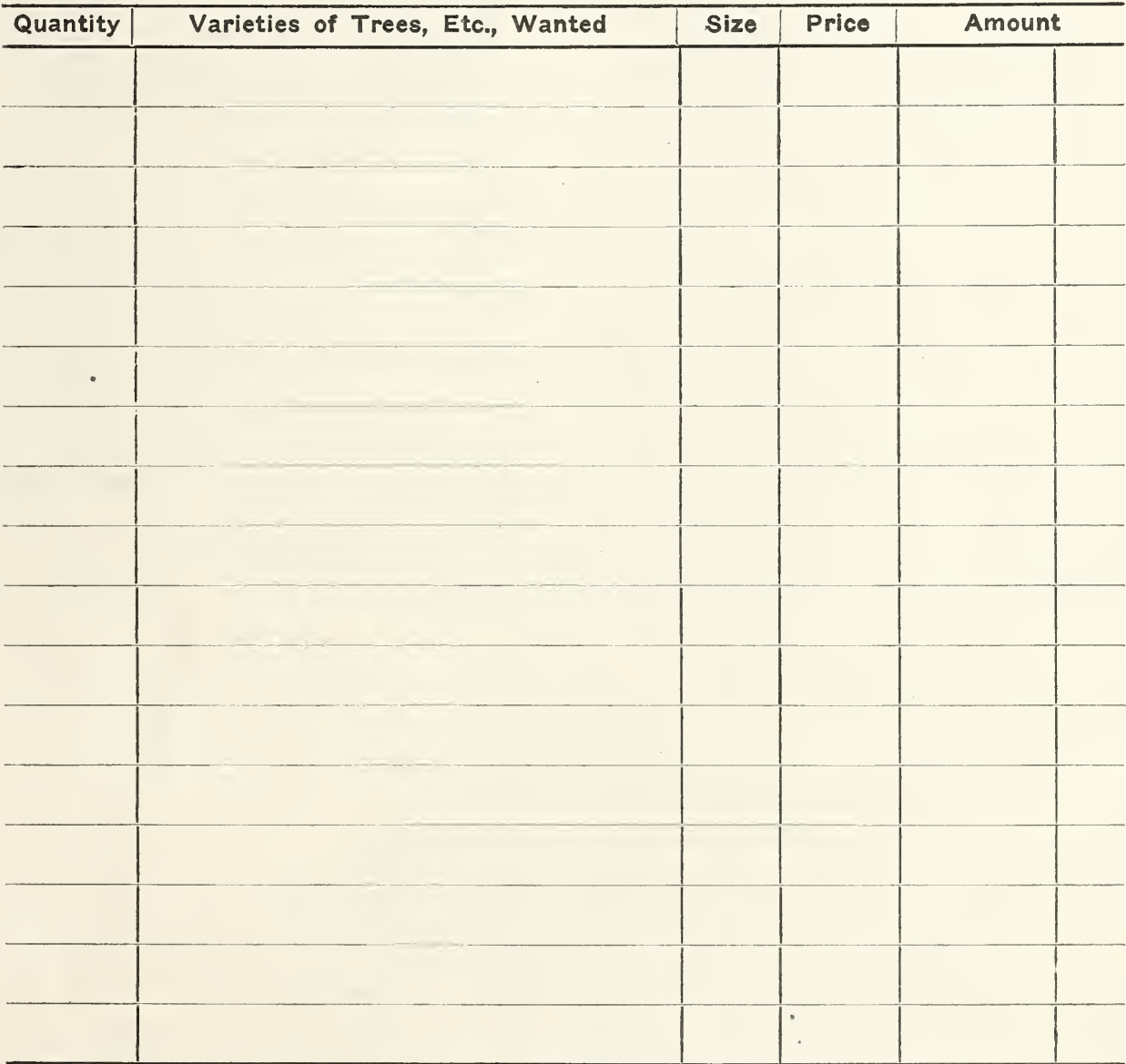




\section{ORDER BLANK}

\begin{tabular}{|c|c|c|c|c|}
\hline Quantity & Varieties of Trees, Etc., Wanted & Size & Price & Amount \\
\hline & Amt. Brought Forward & & & \\
\hline & & & & \\
\hline & & & & \\
\hline & & & & \\
\hline & & & & \\
\hline & & & & \\
\hline & & & & \\
\hline & & & & \\
\hline & & & & . \\
\hline & & & & \\
\hline & & & & \\
\hline & & & & \\
\hline & & & & \\
\hline & & & & \\
\hline & & & & \\
\hline & & & & $\cdot$ \\
\hline & & & & \\
\hline & & & & \\
\hline
\end{tabular}

Names of Friends Who May Be Interested in Our Goods 


\section{Spraying}

Spraying is a vital necessity if you want GOOD Fruit. It doesn't pay to miss one season, even if enemies are not visible. Spraying has an invigorating effect on trees, besides controlling enemies.

Spraying during the dormant period is distinctly different from spraying on foliage. Materials several times as strong can be used and are needed to control the scales.

On account of the life habits of enemies, of ten only two to seven days are available for any one spraying. Do the work then. Put the material on with force and cover every inch of bark and leaf.

Get a sprayer that is big enough, that will give one hundred to two hundred and fifty pounds of air pressure, that is adapted to your land and trees, and that is durable. Get a power outfit, if possible, for it does better work than a hand pump can.

The Spraying program ordinarily resolves itself into two, three or four applications, one while trees are dormant with SCALECIDE, and the others on blossoms and fruit with SULFOCIDE. All applications must be guided by careful study.

Spraying will pay bigger dividends than anything you can do. Anything that is worth having is certainly worth taking care of.

BORERS WILL ATTACK FRUIT TREES IN SPITE OF ALL WE CAN DO, and will kill many trees if left alone. Trees must be gone over several times each year, and should be gone over each April and August.

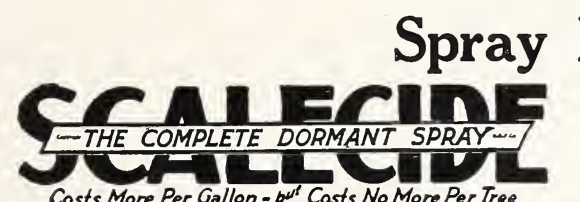

Costs More Per Gallon - pul' Costs No More Per Tree

Scaleclde is truly the complete dormant spray. Applied in the fall It controls scale of all kinds, bud-moth, pear pyslla, peach leaf-curl, and fungous cankers. The delayed dormant spray with Scalecide controls scale, aphis, pear thrips, leaf miner, case bearer, leaf roller European red mite, bud-moth, and fungous cankers. And in addition year after year use of Scalecide invigorates the trees. Scalecide is guaranteed to make a better orchard than lime-sulfur.

Scalecide is pleasant to use; it does not inJure even the eyes. It Is non-poisonous. It saves half the labor of spraying-a tankful of dilute scalecide goes as far as two tankfuls of dilute lime-sulfur. Scalecide saves the cost of nicotine; saves the cost of spreader; saves more than three-fourths the freight and haulage. A fifteen-gallon drum of Scaleclde covers the same trees as a fifty-gallon barrel of limesulfur.

\section{PROPORTIONS}

For small quantities of spray solution, these figures will help you to get the proper mixture. Be accurate.

\section{MATERIAL}

Scalecide-Dilution recommended, 1 gallon to 15 gallons of water. 3 cupsful (11/2 pints), equivalent for 3 gallons of water.

Sulfocide-Dilution recommended, 1 gallon to 200 gallons of water.

4 tablespoonsful ( 2 ounces), equivalent for 3 gallons of water.

\section{PRICES}

\section{Scalecide}

50 -gal. bbls..... $\$ 35.00$

30 -gal. bbls..... 25.00

15 gals. $\$ 11.50$

Drum re- 13.50

turnable 2.00
-gal. can..... 10.60

$\begin{array}{rr}\text { 10-gal. can...... } & 10.60 \\ \text { 5-gal. can..... } & 6.25\end{array}$

5-gal. can......
1 -gal. can..... 1.75

1 -qt. can......... Pints, quarts and gallons shipped by express or parcel post only. F. O. B. NEW HAVEN, MO.

\section{Sulfocide}

50 -gal. bbls.... $\$ 60.00$ 30 -gal. can..... 39.00 10 -gal. can..... 15.00 5-gal. can..... 8.75

1-gal. can.....2.75

1 -qt. can...... 1.00

1 -pt. can...... $\quad .70$
Materials

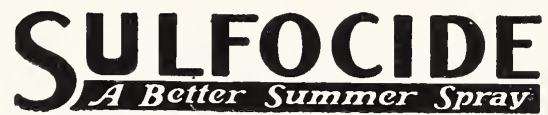

Sulfoclde Is a highly concentrated non-polson. ous liquid sulfur fungicide-entirely distinct from lime-sulfur. Within a few minutes after the spray is applied and before it is dry, sulfocide is decomposed by the action of the alr leaving a film of extremely fine sulfur in its most active fungicidal form.

Briefly these are the reasons why sulfoclde is a better summer spray: it does not russet apples (bordeaux does); it does not devitalize foilage and dwarf the fruit (lime-sulfur does); it can be used on both peaches and apples and on all kind's of fruits and vegetables (no other fungicide can). It imparts to fruit a beautiful luster and finish. It costs no more than home-made bordeaux.

AMOUNTS OF DILUTE SPRAY REQUIRED

These figures will be fairly accurate for both Scalecide as a dormant spray and Sulfocide as a summer spray.

2 to 5 -year-old trees........... 1/8 to $1 / 4 \mathrm{gal}$.

6 to 8 -year-old trees............ $3 / 4$ to 1 gal.

9 to 13 -year-old trees........... 14 to 18 -year-old trees............ 19 to 24 -year-old trees........... 25 to 30 -year-old trees...........

\section{Spray Pumps}

We are agents for the well-known Myers Pumps.

If sizes quoted do not meet your requirements, send for full information and quotations on larger sizes.

No. $129621 / 2$ Gal. Galvanized Tank ....\$ 5.50 No. $1296 \mathrm{~B} 2 \frac{1}{2}$ Gal. Brass Tank .......... 8.75 No. $12974 \frac{1}{2}$ Gal. Galvanized Tank ....... 6.75 No. 1297B 41\% Gal. Brass Tank ......... 10.50 $3 / 8$-inch Three-Ply Hose ..........15c per foot The above are Compressed $\ddot{A}$ ir Sprayers with shoulder Straps.

\section{Cog Gear Barrel Pumps}

\section{(Barrel not Included)}

No. R305B-Spray Pump with one lead of $15-\mathrm{ft}$ $1 / 2$-inch, 5-ply discharge hose; graduating Vermorel Nozzle, and both jet and mechanical agitators.

Each .....................\$15.00

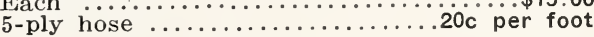




\section{Planting and Pruning}

\section{Care of Stock}

The bundles should be opened, the roots dipped in water, then "heeled-in" in moist ground so that the mellow earth will come in contact with the roots and thoroughly protect them from the air, having the earth tramped solid about them. When ready to plant, take up only a few at a time, puddle the roots and do not allow them to lie exposed to the sun or air. The ground should be carefully prepared by deep plowing and firming down with a disc and harrow.

\section{Planting}

The holes for planting must be large enough to receive the roots freely, without cramping or bending them from their natural position. All broken or mutilated portions of the roots must be cut off so as to leave the ends smooth and sound. All trees should be planted about as they stood in the nursery row; pack the soil very firmly about the roots, being careful not to bark or break the roots. Leave three inches of the surface soil loose to serve as a mulch. If the ground is very dry apply one or two pails of water before this soil mulch is in place, and after the water has soaked away it can then be placed over the moist soil.

\section{Pruning When Planted}

All fruit trees require more or less pruning when planted, and thereafter from year to year. On Apple, Pear and Cherry remove unnecessary branches and cut back growth of remaining branches to insure good growth the first season. On Plum and Peach remove branches to within one inch of body of tree,and cut back the top leader to the desired height for a new head. The usual rule with Peach and Plum is to prune to rough stick form to about three feet in height. The above instructions on pruning are for freshly planted trees only.

\section{Mulching}

Unless thorough surface cultivation will be practiced during the summer a mulch should be applied. This may be a layer of coarse manure or vegetable matter around the trees three to six inches deep, and extending out from the trees three to five feet. Mulching protects the soil against the sun and drying winds; against alternate freezing and thawing, and provides some plant food.

\section{Shrubs}

If planted in beds or groups the ground should be spaded deeply and well worked. If shrubs are set as individual specimens they should be planted the same as trees.

\section{Hedges}

Privet-Dig trench about twelve inches deep and set the plants two to three inches deeper than they stood in the nursery row, or deep enough so the lower branches will be partly under the ground. Such planting will make a compact hedge down to the ground line, but if the plants are set too shallow there will always be undesirable open spaces at the base of the hedge. Privet and Spirea can be set about nine inches apart in the row. Cut back to about six inches of the ground after planting.

\section{Treatment of Nursery Stock}

That Has Been Frozen in the Packages or Received During Freezing Weather.

Place the package UNOPENED in a cellar or some such place that is COOL but free from frost, until completely thawed. DON'Tbe in a hurry to open. The stock can remain in the packages for TWO WEEKS OR LONGER if necessary, without injury. If boxes are covered with sawdust, earth or something to exclude the air, it will be better.

After the FROST is ALL OUT the stock can be opened up and treated as above.

\section{New Haven Nurseries, New Haven, Mo.}




\section{General Information}

\section{About Agents}

This Price List is our Agent, but we shall be pleased to have you secure orders from your neighbors on Club Lot basis. On Club Orders amounting to $\$ 25.00$ or more, on orders at the single, ten and hundred rates, we will allow you $10 \%$ additional in stock. It should be very easy for you to get the stock you want absolutely free. We put up each order in a separate package, so that upon receipt of goods you have only to hand out the different lots as ordered. Special prices will be made on larger quantities than indicated in this list.

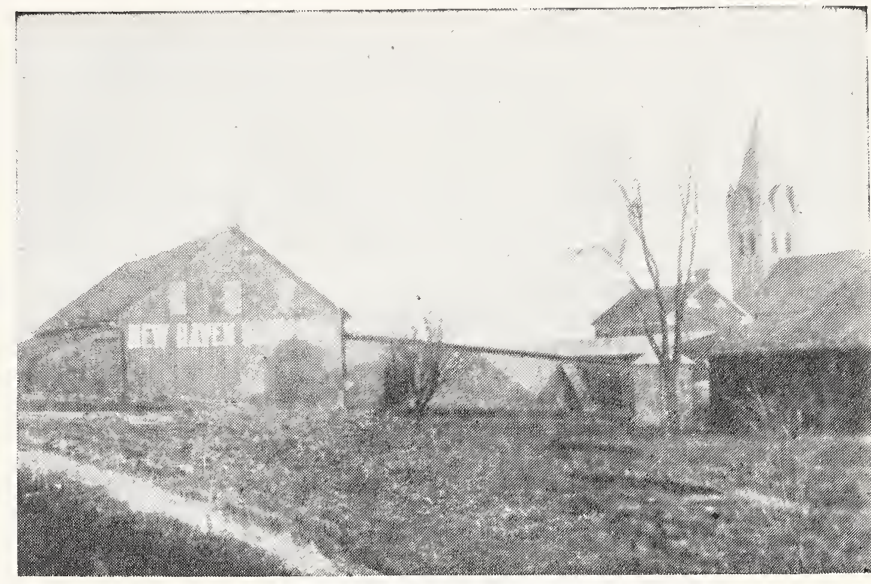

View of Our Storage Sheds

\section{References}

We refer to any bank or business house in New Haven, Mo., as to our responsibility and standing in the community. We do our local business with the Farmers Savings Bank, New Haven, Mo.

\section{Distances for Planting}

Standard Apples................................... feet apart each way Standard Pears and Strong-growing Cherries...............20 feet apart each way Duke and Morello Cherries............................ feet apart each way Standard Plums, Apricots.......................... to 20 feet apart each way

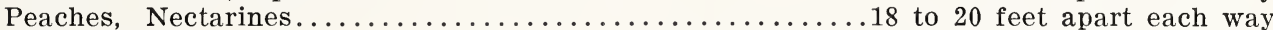
Dwarf Pears........................................... to 20 feet apart each way Grapes ........................... 10 to 16 feet apart, 7 to 16 feet in rows Currants and Gooseberries....................................... 4 feet apart Raspberries and Blackberries......................... to 4 by 5 to 7 feet apart Strawberries for field culture...................... to $11 \frac{2}{2}$ by 3 to 4 feet apart Strawberries for garden culture.................................. to 2 feet apart

\section{Number of Trees on an Acre}

30 feet apart each way............ 50 18 feet apart each way............ 135

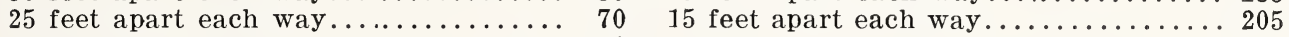

20 feet apart each way............. 110

Rule-Multiply the distance in feet between the rows by the distance the plants are apart in the rows, and the product will be the number of square feet for each plant or hill; which, divided into the number of square feet in an acre $(43,560)$, will give the number of plants or trees to the acre.

Proper planting and cultivation with correct pruning is the best insurance on an orchard.

\section{We Grow Our Own Stock}

We mail this list of prices to our friends and customers, and will ask that they favor us with their orders as early as practicable. We have now growing in our nurseries over one million fruit and shade trees. All clean and healthy. ENTOMOLOGIST'S CERTIFICATE WITH EACH SHIPMENT.

Shipments to Pacific Coast and Southern States from our frost-proof storage during winter months via Southern Routes.

WE ARE GROWERS OF WHAT WE SELL. Many nurserymen are simply jobbers in the trade, and cannot sell stock with the same certainty of being true to name and free from disease. 


\title{
THE MISSOURI STATE BOARD OF AGRICULTURE
}

\author{
Office of the Plant Commissioner \\ Jefferson City
}

CERTIFICATE OF NURSERY INSPECTION

No. 3.

Issued September 11, 1929.

THIS IS TO CERTIFY that, in accordance with the provisions of the Missouri Plant Act of 1929, the nursery and premises thereof belonging to New Haven Nurseries of New Haven, Mo., have been inspected by a duly authorized inspector and were found to be apparently free of injurious insect pests and plant diseases.

This certificate is not transferable and may be revoked for cause. This certificate expires September 1, 1930.

K. C. SUllivaN, Plant Commissioner.

We are prepared to fumigate all consignments to states requiring fumigation. No Scale or Yellows has ever been found in our establishment, and we take pride in sending out only clean, healthy stock.

\section{It Pays to Plant}

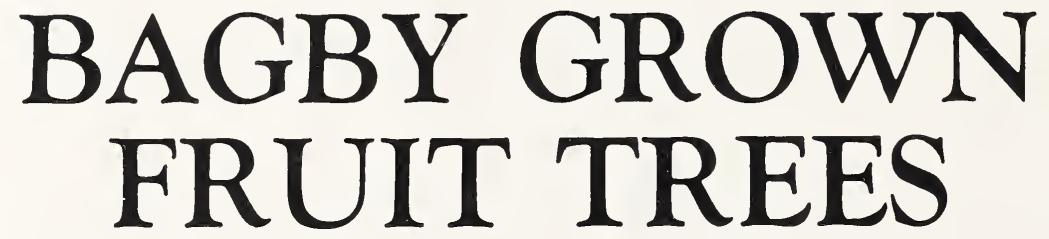

\section{They Grow and Bear True To Name}

When you buy Fruit Trees, you want the best that can be produced. BAGBY GROWN trees have been on the market for fifty-eight years. When you buy them you are getting the best money can purchase, and you know what the crop will be. Our varieties are correct, our grades full, and all culls go on the brush pile. High quality and

\section{ABSOLUTE SATISFACTION GUARANTEED}

with a record of over fifty-eight years' square dealing to back the guaranty.

VISITORS ALWAYS WELCOMED AT OUR NURSERIES.

It will be a pleasure to show you our stock.

NEW HAVEN NURSERIES, New Haven, Missouri J. BAGBY \& SONS COMPANY

BAGBY Trees are Full of Vitality Because They Are Grown Right They Bring Results

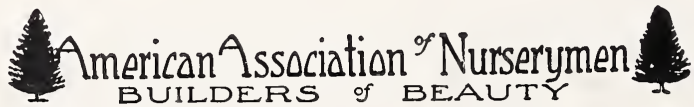

